\title{
STUDIES IN STEROID METABOLISM. XXVIII. THE $\alpha$-KETO- STEROID EXCRETION PATTERN IN NORMAL FEMALES AND THE RESPONSE TO ACTH ${ }^{1}$
}

\author{
By ATTALLAH KAPPAS ${ }^{2}$ AND T. F. GALLAGHER
}

\author{
(From the Sloan-Kettering Institute for Cancer Research, New York, N. Y.)
}

(Submitted for publication April 18, 1955 ; accepted May 25, 1955)

An examination of the urinary $\alpha$-ketosteroids has been made in normal women in order to provide information about this important group of hormone metabolites. These data establish limits of values for the major components of this group of steroids and thus provide not only a suitable comparison for studies in abnormal or altered hormonal physiology, but offer information about possible sex differences in the composition of these hormonal metabolites as well. The qualitative and quantitative $\alpha$-ketosteroid excretion pattern of a series of normal males has been reported earlier from this laboratory (1).

Two of the pre-menopausal women were studied at successive intervals throughout the menstrual cycle. The results provide evidence that the precursors of the major urinary neutral ketosteroids in normal women are secreted independently of this pituitary-ovarian rhythm. In addition, two other normal young women were studied during control periods as well as during successive periods while under vigorous stimulation with adrenocorticotrophic hormone (ACTH). The results provide information on the character of this adrenal response in women, and are thus helpful in the interpretation of abnormal hormonal situations, an example of which is described in a recent study (2).

The development of methods for more satisfactory hydrolysis of urinary steroid conjugates, improvement in the techniques of separation, particularly partition column and paper chromatography

1 The investigation was supported in part by a grantin-aid from the American Cancer Society, upon recommendation of the Committee on Growth of the National Research Council, the Lillia Babbitt Hyde Foundation and a research grant, C-322, from the National Cancer Institute of the National Institutes of Health; U. S. Public Health Service.

2 Research Fellow of the American Cancer Society upon recommendation of the Committee on Growth of the National Research Council. and increased facility in the recognition of individual compounds by infrared spectrophotometry afford a high degree of assurance about the reproducibility of the data. Thus, while the number of individuals studied is small, physiologic interpretation and projection to the normal female population is permissible with a high degree of probability.

\section{EXPERIMENTAL}

Eight normal healthy white females, described by initial and age were studied; M22, W25, S33, F38, B43, N47 were pre-menopausal and G53, W62 were postmenopausal. Subject S33 was studied during 3 consecutive periods throughout a single menstrual cycle; subject F38 was studied similarly during 4 consecutive periods. The steroid values reported for these two subjects represent the averages of these replicate steroid patterns: the reproducibility of these patterns was excellent. Subject M22 was studied during 6 consecutive periods. Following a six-day control period (Period 1) 80 units of ACTH (Armour Laboratories H. P. Acthar Gel) were administered daily in a single dose intramuscularly for 3 consecutive three-day periods ( $\mathrm{Pe}$ riods 2, 3, and 4). Following this treatment, two consecutive post control periods, totalling six days (Periods 5 and 6) were studied.

Subject W25 was studied similarly employing the same dose of ACTH gel. The ACTH period was, however, slightly shorter (see Periods 2, 3 and 4, Table IV). Both subjects became slightly edematous towards the end of the period of ACTH administration; no other untoward effects were noted. Diuresis occurred promptly following the termination of treatment.

All subjects were ambulatory. Complete urine collections were obtained and were checked by means of daily creatinine determinations. Urines were refrigerated until processed, which was usually begun one or two days following the completion of each three-day period. Enzymatic and acid hydrolysis of the urinary steroid conjugates was accomplished according to the following method, which for reference purposes (see Methods A, B, C, and D [1]) is called Method E. The details are as follows: Method $E$. Stage 1 . The urine was adjusted to $\mathrm{pH} 5$ with sulfuric acid; 10 per cent by volume of sodium acetate buffer at $\mathrm{pH} 5$ and 300,000 units per liter of beef liver $\beta$-glucuronidase were added. The solu- 
TABLE I

The urinary steroid excretion pattern in normal females

\begin{tabular}{|c|c|c|c|c|c|c|c|c|}
\hline \multirow{2}{*}{\begin{tabular}{ll} 
& \multicolumn{1}{c}{ Compounds } \\
Total $C_{10}$ & 11 -oxysteroids \\
Total $C_{10}$ & 11 -desoxysteroids
\end{tabular}} & \multicolumn{8}{|c|}{ Milligrams per 24 hours } \\
\hline & $\begin{array}{l}1.5 \\
5.7\end{array}$ & $\begin{array}{l}1.6 \\
4.7 \\
\end{array}$ & $\begin{array}{l}1.6 \\
3.6\end{array}$ & $\begin{array}{l}1.1 \\
2.3\end{array}$ & $\begin{array}{l}1.0 \\
1.6\end{array}$ & $\begin{array}{l}1.6 \\
3.1\end{array}$ & $\begin{array}{l}2.4 \\
2.3\end{array}$ & $\begin{array}{l}1.4 \\
0.4 \\
\end{array}$ \\
\hline $\begin{array}{l}3 \alpha \text {-Hydroxyetiocholane-11,17-dione } \\
3 \alpha, 11 \beta \text {-Dihydroxyetiocholane-17-one } \\
3 \alpha, 11 \beta \text {-Dihydroxyandrostane-17-one }\end{array}$ & $\begin{array}{l}0.6 \\
0.5 \\
0.4\end{array}$ & $\begin{array}{l}0.6 \\
0.4 \\
0.6\end{array}$ & $\begin{array}{l}0.6 \\
0.5 \\
0.5\end{array}$ & $\begin{array}{l}0.3 \\
0.3 \\
0.5\end{array}$ & $\begin{array}{l}0.4 \\
0.3 \\
0.3\end{array}$ & $\begin{array}{l}0.5 \\
0.6 \\
0.5\end{array}$ & $\begin{array}{l}0.7 \\
1.1 \\
0.6\end{array}$ & $\begin{array}{l}0.5 \\
0.4 \\
0.5\end{array}$ \\
\hline $\begin{array}{l}\text { Etiocholanolone } \\
\text { Androsterone }\end{array}$ & $\begin{array}{l}3.2 \\
2.5\end{array}$ & $\begin{array}{l}3.2 \\
1.5\end{array}$ & $\begin{array}{l}2.2 \\
1.4\end{array}$ & $\begin{array}{l}1.4 \\
0.9\end{array}$ & $\begin{array}{l}0.9 \\
0.7\end{array}$ & $\begin{array}{l}1.7 \\
1.4\end{array}$ & $\begin{array}{l}1.6 \\
0.7\end{array}$ & $\begin{array}{l}0.2 \\
0.2\end{array}$ \\
\hline $\begin{array}{l}\beta \text { Ketonic KS } \\
\alpha \text { Ketonic KS } \\
\text { Ketonic KS } \\
\text { Crude KS }\end{array}$ & $\begin{array}{r}0.5 \\
9.5 \\
10.0 \\
13.7\end{array}$ & $\begin{array}{r}0.3 \\
7.2 \\
9.1 \\
11.7\end{array}$ & $\begin{array}{r}1.2 \\
10.4 \\
12.5 \\
18.6\end{array}$ & $\begin{array}{r}0.1 \\
6.1 \\
7.2 \\
13.4\end{array}$ & $\begin{array}{r}0.2 \\
5.6 \\
5.7 \\
11.1\end{array}$ & $\begin{array}{l}0.1 \\
6.3 \\
6.9 \\
9.6\end{array}$ & $\begin{array}{r}1.3 \\
9.1 \\
11.5 \\
29.5\end{array}$ & $\begin{array}{l}0.02 \\
3.2 \\
3.5 \\
9.6 \\
\end{array}$ \\
\hline $\begin{array}{l}\text { Collection days } \\
\text { Patient-Age }\end{array}$ & $\begin{array}{r}6 \\
\mathrm{M} 22\end{array}$ & $\begin{array}{r}6 \\
\mathrm{~W} 25\end{array}$ & S33 & $\begin{array}{r}* \\
\text { F38 }\end{array}$ & $\begin{array}{r}20 \\
\mathrm{~B} 43\end{array}$ & $\begin{array}{r}10 \\
\mathrm{~N} 47\end{array}$ & $\begin{array}{r}10 \\
\text { G53 }\end{array}$ & $\begin{array}{r}9 \\
\text { W62 }\end{array}$ \\
\hline
\end{tabular}

* Average of values of replicate patterns.

tion was incubated at $37^{\circ}$ for 120 hours, then adjusted to pH 1 with sulfuric acid and extracted with ether for 48 hours. The "crude neutral fraction" was obtained by extracting this ether solution with $2 \mathrm{~N}$ sodium hydroxide, followed by washes with 5 per cent sodium chloride solution until neutral.

Stage 2. The alkali soluble material and the sodium chloride washes were combined with the spent urine from Stage 1, and adjusted to acidity equivalent to $1 \mathrm{~N}$ sulfuric acid. This solution was then extracted for 72 hours with ether. A second "crude neutral fraction" was obtained from the ether extract as in Stage 1.

These two "crude neutral fractions" were individually separated into ketonic and non-ketonic fractions by means of Girard's "Reagent T," and into $\alpha$ and $\beta$-ketosteroid subfractions by precipitation with digitonin. These methods have been described in detail (3). The $\alpha$-ketosteroid fractions were separately chromatographed.

In the majority of instances separation of the indi- vidual steroids was accomplished both by column partition chromatography (4), as well as by paper chromatography employing the systems of Burton, Zaffaroni, and Keutmann (5) and the modifications applicable to the less polar ketosteroids (6). For the partition columns, silica gel containing ethanol was used as the stationary phase and methylene chloride containing small amounts of ethanol was the mobile phase (4). Appropriate portions of each neutral extract were separated by both procedures and it was demonstrated that if the proper precautions were exercised, the agreement of the two methods was excellent. As a consequence, in the later portions of the study the more rapid paper chromatography was employed exclusively; wherever advisable, the identity of individual components was established by means of infrared spectrometry. The material from Stage 2 was separated by paper chromatography only. The quantitative analysis of the separated steroids was done by the Zimmermann reaction (as modified by

TABLE II

Replicate steroid pattern in normal females

\begin{tabular}{|c|c|c|c|c|c|c|c|}
\hline \multirow{2}{*}{\begin{tabular}{ll}
\multicolumn{1}{c}{ Compounds } \\
Total $C_{19}$ & 11 -oxysteroids \\
Total $C_{19}$ & 11 -desoxysteroids
\end{tabular}} & \multicolumn{7}{|c|}{ Milligrams per 24 hours } \\
\hline & $\begin{array}{l}1.3 \\
3.7\end{array}$ & $\begin{array}{l}1.9 \\
3.7\end{array}$ & $\begin{array}{l}1.7 \\
3.6\end{array}$ & $\begin{array}{l}0.7 \\
2.5\end{array}$ & $\begin{array}{l}1.0 \\
2.6\end{array}$ & $\begin{array}{l}1.1 \\
2.0\end{array}$ & $\begin{array}{l}1.2 \\
2.2\end{array}$ \\
\hline $\begin{array}{l}3 \alpha \text {-Hydroxyetiocholane-11,17-dione } \\
3 \alpha, 11 \beta \text {-Dihydroxyetiocholane-17-one } \\
3 \alpha, 11 \beta \text {-Dihydroxyandrostane-17-one }\end{array}$ & $\begin{array}{l}0.4 \\
0.5 \\
0.4\end{array}$ & $\begin{array}{l}0.7 \\
0.6 \\
0.6\end{array}$ & $\begin{array}{l}0.7 \\
0.4 \\
0.6\end{array}$ & $\begin{array}{l}0.2 \\
0.2 \\
0.3\end{array}$ & $\begin{array}{l}0.3 \\
0.3 \\
0.4\end{array}$ & $\begin{array}{l}0.2 \\
0.2 \\
0.7\end{array}$ & $\begin{array}{l}0.4 \\
0.4 \\
0.4\end{array}$ \\
\hline $\begin{array}{l}\text { Etiocholanolone } \\
\text { Androsterone }\end{array}$ & $\begin{array}{l}2.2 \\
1.5\end{array}$ & $\begin{array}{l}2.2 \\
1.5\end{array}$ & $\begin{array}{l}2.3 \\
1.3\end{array}$ & $\begin{array}{l}1.4 \\
1.1\end{array}$ & $\begin{array}{l}1.6 \\
1.0\end{array}$ & $\begin{array}{l}1.2 \\
0.8\end{array}$ & $\begin{array}{l}1.4 \\
0.8\end{array}$ \\
\hline $\begin{array}{l}\beta \text { Ketonic KS } \\
\alpha \text { Ketonic KS } \\
\text { Ketonic KS } \\
\text { Crude KS }\end{array}$ & $\begin{array}{r}2.0 \\
9.8 \\
12.9 \\
23.9\end{array}$ & $\begin{array}{r}1.0 \\
10.7 \\
12.3 \\
16.6\end{array}$ & $\begin{array}{r}0.8 \\
10.5 \\
12.3 \\
16.8\end{array}$ & $\begin{array}{r}0.1 \\
6.3 \\
7.5 \\
12.8\end{array}$ & $\begin{array}{r}0.1 \\
5.4 \\
7.2 \\
13.6\end{array}$ & $\begin{array}{r}0.1 \\
6.6 \\
7.8 \\
13.9\end{array}$ & $\begin{array}{r}0.1 \\
6.0 \\
6.4 \\
13.4\end{array}$ \\
\hline $\begin{array}{l}\text { Collection days } \\
\text { Period No. }\end{array}$ & $\begin{array}{r}6 \\
1-2\end{array}$ & $\begin{array}{r}9 \\
3 \\
\text { S33 }\end{array}$ & $\begin{array}{l}8 \\
4\end{array}$ & $\begin{array}{r}6 \\
1-2\end{array}$ & $\begin{array}{c}6 \\
3-4 \\
\text { F38 }\end{array}$ & $\begin{array}{l}3 \\
5\end{array}$ & $\begin{array}{r}6 \\
6-7\end{array}$ \\
\hline
\end{tabular}


TABLE III

The ketosteroid excretion of a girl before, during and after ACTH-Subject $M 22$

\begin{tabular}{|c|c|c|c|c|c|c|}
\hline \multirow{2}{*}{\begin{tabular}{ll}
\multicolumn{1}{c}{ Compounds } \\
Total $C_{19}$ & 11 -oxysteroids \\
Total $C_{19}$ & 11 -desoxysteroids
\end{tabular}} & \multicolumn{6}{|c|}{ Milligrams per 24 hours } \\
\hline & $\begin{array}{l}1.5 \\
5.7\end{array}$ & $\begin{array}{r}5.3 \\
11.4\end{array}$ & $\begin{array}{r}4.9 \\
13.5\end{array}$ & $\begin{array}{r}6.2 \\
15.4\end{array}$ & $\begin{array}{l}2.6 \\
6.2\end{array}$ & $\begin{array}{l}1.5 \\
3.4\end{array}$ \\
\hline $\begin{array}{l}3 \alpha \text {-Hydroxyetiocholane-11,17-dione } \\
3 \alpha, 11 \beta \text {-Dihydroxyetiocholane-17-one } \\
3 \alpha, 11 \beta \text {-Dihydroxyandrostane-17-one }\end{array}$ & $\begin{array}{l}0.6 \\
0.5 \\
0.4\end{array}$ & $\begin{array}{l}1.6 \\
2.4 \\
1.3\end{array}$ & $\begin{array}{l}1.8 \\
2.3 \\
0.8\end{array}$ & $\begin{array}{l}2.0 \\
2.8 \\
1.4\end{array}$ & $\begin{array}{l}1.0 \\
1.1 \\
0.5\end{array}$ & $\begin{array}{l}0.5 \\
0.4 \\
0.6\end{array}$ \\
\hline $\begin{array}{l}\text { Etiocholanolone } \\
\text { Androsterone }\end{array}$ & $\begin{array}{l}3.2 \\
2.5\end{array}$ & $\begin{array}{l}7.6 \\
3.8\end{array}$ & $\begin{array}{l}9.4 \\
4.1\end{array}$ & $\begin{array}{r}10.2 \\
5.2\end{array}$ & $\begin{array}{l}4.2 \\
2.0\end{array}$ & $\begin{array}{l}2.2 \\
1.2\end{array}$ \\
\hline Dehydroisoandrosterone & 0.4 & 1.0 & 3.4 & 6.2 & 0.4 & tr. \\
\hline $\begin{array}{l}\beta \text { Ketonic KS } \\
\alpha \text { Ketonic KS } \\
\text { Ketonic KS } \\
\text { Crude KS }\end{array}$ & $\begin{array}{r}0.5 \\
9.5 \\
10.0 \\
13.7\end{array}$ & $\begin{array}{r}1.9 \\
17.8 \\
22.2 \\
26.3\end{array}$ & $\begin{array}{r}5.8 \\
21.3 \\
28.0 \\
30.7\end{array}$ & $\begin{array}{r}8.0 \\
24.2 \\
36.9 \\
37.8\end{array}$ & $\begin{array}{r}0.9 \\
11.5 \\
14.3 \\
18.1\end{array}$ & $\begin{array}{r}0.2 \\
6.4 \\
7.6 \\
11.6\end{array}$ \\
\hline $\begin{array}{l}\text { Collection days } \\
\text { Period No. } \\
\text { Therapy }\end{array}$ & $\begin{array}{c}6 \\
1 \\
\text { (Control) }\end{array}$ & $\begin{array}{l}3 \\
2\end{array}$ & $\begin{array}{r}3 \\
3 \\
\mathrm{CTH}\end{array}$ & ds) $\begin{array}{r}3 \\
4\end{array}$ & $\begin{array}{c}2 \\
5 \\
(\mathrm{Pos}\end{array}$ & $\begin{array}{c}4 \\
4 \\
6 \\
\text { ontrol) }\end{array}$ \\
\hline
\end{tabular}

Callow, Callow, Emmens, and Stroud $(7,8)$ and Talbot, Butler, MacLachlan, and Jones (9). Appropriate factors were used to correct the color values from $\mathrm{mg}$. of dehydroisoandrosterone, used as standard, to $\mathrm{mg}$. of the actual compound determined in the chromatographic fraction, since ketosteroids differ somewhat in chromogenic value $(10)$.

\section{RESULTS}

The quantitative data on the $\alpha$-ketonic steroid excretion are given in Tables I, II, III, and IV. Subjects are described by initial and age. Table I lists these data for the eight normal subjects; values are reported for the crude neutral as well as the various fractions obtained prior to separa- tion of the individual components. As noted earlier (1), the high values for crude extracts are the result of relatively complete extraction of ketones, non-ketones and non-specific chromogens. The values for the ketonic fraction are a closer approximation of the sum of the individual components.

In addition to the compounds reported in the Tables, a number of other ketosteroids are present in small amounts in the urine of normal women. Among the compounds always found in the " $\alpha$-ketosteroid" fraction are: etiocholane-3,17-dione and androstane-3,17-dione, $3 \alpha$-hydroxyandrostane-11,17-dione and $3 \alpha, 17 \alpha$-dihydroxypregnane-

TABLE IV

The ketosteroid excretion of a girl before, during and after $A C T H-S u b j e c t$ W25

\begin{tabular}{|c|c|c|c|c|c|c|}
\hline \multirow{2}{*}{\begin{tabular}{ll}
\multicolumn{1}{c}{ Compounds } \\
Total $C_{19}$ & 11 -oxysteroids \\
Total $C_{19}$ & 11 -desoxysteroids
\end{tabular}} & \multicolumn{6}{|c|}{ Milligrams per 24 hours } \\
\hline & $\begin{array}{l}1.6 \\
4.7\end{array}$ & $\begin{array}{l}2.5 \\
8.8\end{array}$ & $\begin{array}{r}6.1 \\
11.4\end{array}$ & $\begin{array}{l}11.8 \\
18.1\end{array}$ & $\begin{array}{l}4.2 \\
7.7\end{array}$ & $\begin{array}{l}1.5 \\
3.1\end{array}$ \\
\hline $\begin{array}{l}3 \alpha \text {-Hydroxyetiocholane-11,17-dione } \\
3 \alpha, 11 \beta \text {-Dihydroxyetiocholane-17-one } \\
3 \alpha, 11 \beta \text {-Dihydroxyandrostane-17-one }\end{array}$ & $\begin{array}{l}0.6 \\
0.4 \\
0.6\end{array}$ & $\begin{array}{l}0.6 \\
1.1 \\
0.8\end{array}$ & $\begin{array}{l}1.4 \\
2.9 \\
1.8\end{array}$ & $\begin{array}{l}3.0 \\
5.5 \\
3.5\end{array}$ & $\begin{array}{l}1.2 \\
2.4 \\
0.6\end{array}$ & $\begin{array}{l}0.4 \\
0.6 \\
0.5\end{array}$ \\
\hline $\begin{array}{l}\text { Etiocholanolone } \\
\text { Androsterone }\end{array}$ & $\begin{array}{l}3.2 \\
1.5\end{array}$ & $\begin{array}{l}6.1 \\
2.7\end{array}$ & $\begin{array}{l}7.7 \\
3.7\end{array}$ & $\begin{array}{r}12.7 \\
5.4\end{array}$ & $\begin{array}{l}5.3 \\
2.4\end{array}$ & $\begin{array}{l}2.1 \\
1.0\end{array}$ \\
\hline Dehydroisoandrosterone & 0.1 & 0.4 & 0.3 & 1.5 & 0.6 & tr. \\
\hline $\begin{array}{l}\beta \text { Ketonic KS } \\
\alpha \text { Ketonic KS } \\
\text { Ketonic KS } \\
\text { Crude KS }\end{array}$ & $\begin{array}{r}0.3 \\
7.2 \\
9.1 \\
11.7\end{array}$ & $\begin{array}{r}0.8 \\
15.6 \\
16.5 \\
20.2\end{array}$ & $\begin{array}{r}1.1 \\
21.4 \\
20.7 \\
25.3\end{array}$ & $\begin{array}{r}2.4 \\
40.3 \\
42.5 \\
45.0\end{array}$ & $\begin{array}{r}0.9 \\
17.7 \\
18.4 \\
24.7\end{array}$ & $\begin{array}{r}\overline{7} \\
\overline{7.6} \\
13.7\end{array}$ \\
\hline $\begin{array}{l}\text { Collection days } \\
\text { Period No. } \\
\text { Therapy }\end{array}$ & $\begin{array}{c}6 \\
1 \\
\text { (Control) }\end{array}$ & $\begin{array}{l}2 \\
2\end{array}$ & $\begin{array}{r}2 \\
3 \\
\mathrm{TH} \mathrm{P}\end{array}$ & ds) $\begin{array}{r}3 \\
4\end{array}$ & $\begin{array}{c}3 \\
5 \\
\text { (Pos }\end{array}$ & $\begin{array}{c}3 \\
6 \\
\text { ontrol) }\end{array}$ \\
\hline
\end{tabular}


20 -one ; ${ }^{3}$ small amounts of $3 \beta$-hydroxyetiocholane17 -one are usually found in the $\alpha$-ketosteroid fraction and occasionally in the $\beta$-ketosteroid fraction. Usually, but not invariably, pregnanolone was present and $11 \beta$-hydroxyandrostane-3,17-dione was sometimes detected in trace amount. If the small $\beta$-ketosteroid fraction is separated into its components, dehydroisoandrosterone is invariably the major compound present, and isoandrosterone accompanies this compound. In addition 7-ketodehydroisoandrosterone is usually found. Quantitative values for these substances have not been included since their contribution to the total is small and separation is often incomplete. It is nevertheless important to note that these, as well as small amounts of other as yet unidentified compounds, probably steroids, are normally present in the ketosteroid fraction.

All three 11-oxygenated steroids (Table I), i.e., $3 \alpha$-hydroxyetiocholane-11,17-dione, $3 \alpha, 11 \beta$ dihydroxyandrostane-17-one, and $3 \alpha, 11 \beta$-dihydroxyetiocholane-17-one were found in approximately equivalent amount in each individual studied and there was relatively little variation from subject to subject. The 11-desoxysteroids, i.e., androsterone and etiocholanolone varied within much wider limits among the different individuals. Etiocholanolone was the major component and consequently exhibited the greatest fluctuation. The significance of these changes will be considered in the discussion.

Table II records the quantitative values for indi-

\footnotetext{
3 The prior failure to recognize $3 \alpha, 17 \alpha$-dihydroxypregnane-20-one as a normal constituent of most urines (11) was the result of a combination of methodological difficulties. Upon vigorous acid hydrolysis, the compound to a very considerable extent is converted to a D-homosteroid. When pure, $3 \alpha, 17 \alpha$-dihydroxypregnane-20-one is almost completely insoluble in carbon disulfide and soluble with difficulty in chloroform, so that recognition by infrared spectrometry was hampered. Although the substance was readily recognized in frank adrenal abnormalities where the amount present was relatively large, small amounts escape detection by the means available in the earlier studies. The use of more satisfactory hydrolysis and more efficient separation procedures, combined with greater familiarity of the limitations of infrared spectrometry for this special problem, facilitated the recognition of small amounts of the substance. A method for the quantitative estimation of $3 \alpha, 17 \alpha$-dihydroxypregnane-20-one has been recently developed in these laboratories and will be published in the near future.
}

vidual steroids and the groups from which these were derived, for two normal women during consecutive portions of the menstrual cycle in each subject. Urine collections commenced the first day following the menstrual period and ended the day preceding the onset of the succeeding flow. Thus in the strict sense the whole cycle was not studied. The constancy of the steroid excretion pattern over the intervals, examined, however, provides evidence that there is no marked variation or rhythm in the precursors of the metabolites of the neutral hormones, as distinct from the phenolic ovarian secretions.

Tables III and IV contain comparable data on the ketosteroid excretion of two young girls before, during and after treatment with ACTH. The steroid response to this pituitary hormone was in general terms similar in both subjects. $3 \alpha, 11 \beta$-Dihydroxyetiocholane-17-one showed the greatest relative as well as absolute increase among the 11-oxygenated metabolites. All the 11oxygenated steroids however, were at elevated levels during ACTH stimulation. The 11-desoxysteroids were similarly increased in both subjects. There was a slightly greater rise in etiocholanolone than in androsterone but the proportion of these two compounds did not alter appreciably throughout the experiment in either subject.

In the periods after ACTH the 11-oxygenated steroids quickly returned to normal levels in both girls. The decline in excretion of 11-desoxysteroids was equally prompt and it is of some interest to note that both subjects exhibited a similar pattern. This is evident in Period 6 when, in both girls, the 11-oxygenated metabolites, within experimental error, were at control levels. Despite this fact, the 11-desoxysteroids were appreciably lower than at any time during the study. The fact that the same result was obtained in the two girls, combined with the very considerable confidence with which these compounds can be separated and measured, lends a special significance to the observation despite the lack of statistical numbers and in the face of only a small change in absolute amount of metabolite.

\section{DISCUSSION}

A consideration of the chemical structure of these steroid metabolites and their probable hor- 
monal precursors, makes it likely that these data define certain parameters of adrenocortical function and steroid hormone metabolism in normal women. These functions can be chemically categorized with respect to hormonal precursors with or without the oxygen function at carbon-11 of the steroid nucleus. It is presumed that all the ketosteroids measured in these studies reflect primarily adrenocortical hormones and that the 11-oxygenated steroids represent for the most part end products of hydrocortisone metabolism. The precursors of the 11-desoxysteroids are less well defined and interpretation of their function is more speculative.

As defined by these criteria, the results presented indicate that the synthesis, secretion and metabolism of hydrocortisone in normal women fluctuate only within narrow physiological limits. This is in contrast with the wide variation in 11oxygenated steroids reported earlier for normal males (1). That this represents a real sex difference is problematical. It must be remembered that the studies with normal males were conducted over an extended interval of time during which a number of hydrolytic procedures was employed and while the methods of separation and recognition were constantly being improved. The constancy of the values for 11-oxygenated ketosteroids in this present study may reflect the success of these methodologic advances. While there are variations among the individual subjects, as would be expected on purely physiological grounds, in only one instance (G53; $3 \alpha, 11 \beta$-dihydroxyetiocholane-17-one) was the variation within the group as great as four-fold for a single compound. The variation in excretion of $3 \alpha$-hydroxyetiocholane11,17-dione from subject to subject was only about two-fold in the most widely divergent instances and the amount of $3 \alpha, 11 \beta$-dihydroxyandrostane17 -one measured was even more constant. Nevertheless an interesting feature emerges from these data. The mean value for $C_{10}$ 11-oxygenated steroids in men was approximately $2.0 \mathrm{mg}$. while the corresponding figure for the normal females examined in this study was $1.5 \mathrm{mg}$. The methodological difficulties in the earlier studies, especially the failure to identify $3 \alpha, 11 \beta$-dihydroxyetiocholane-17-one as a normal and sometimes major component of the $\mathrm{C}_{19}$ 11-oxygenated ketosteroids, would indicate that the mean values re- ported for these compounds in males were slightly lower than the true values. It would appear, then, that as a general rule, adrenal function, as defined by these criteria, is at a lower homeostatic level in the female.

Over the age range studied, adrenal function in women is independent of chronological age, as measured by the three $C_{19}$ 11-oxygenated steroids that comprise the major constituents of this group of adrenal metabolites. This conclusion is in agreement with that reported in the normal male series and would lend support to the suggestion of a sex difference in the steady state level of adrenocortical activity. It would be of considerable interest to establish the validity of this conclusion in an extended series by a study of the more highly oxygenated metabolites of hydrocortisone, such as the cortols and cortolones (11) since these appear to represent a larger portion of the total metabolites. Efforts in this direction have already been initiated in this laboratory.

The $\mathrm{C}_{19}$ 11-desoxy ketosteroids in women and in men, as a general rule appear to diminish with age although, as anticipated, there are exceptions to the general trend. The precursors of these products, then, are not restricted to the narrow physiologic limits characteristic of the 11-oxygenated hormones. It seems unlikely that the decrease in 11-desoxysteroids of women with age represents a decline in the ovarian contribution to these metabolites since appropriate precursors have never been demonstrated in the gland. One must, therefore, conclude that there is a selective diminution in certain adrenocortical steroid synthesis, possibly androgen from the nature of the metabolites, that occurs with increasing chronologic age. This same process, inferentially, is operative in the male as well. These findings clearly require confirmation and elaboration with a larger group of subjects since the theoretical and practical import is apparent.

It is evident from the data presented in Table II that the secretion and metabolic transformation of the hormonal precursors of the $\mathrm{C}_{19} \alpha$-ketosteroid metabolites measured is not subject to marked fluctuation during the examined intervals of a menstrual cycle. These results do not preclude some alteration during active menstrual flow. With this reservation, the conclusion is of some importance in that it facilitates comparison of 
data from random collections as well as between pre- and post-menopausal subjects with respect to the metabolites studied. In addition, it is of value for the further study of the sex difference suggested by the results of this report and extension of these findings to a comparison of normal and diseased subjects. While it may be desirable to study this problem more intensively with a view to daily variations that may be obscured in the longer term studies, these aspects must await the development of more rapid and easily applied methods.

The steroid response to ACTH in the normal females studied was characterized by a prompt and progressive increase in all the compounds measured. The magnitude of this response testifies to the more effective adrenocortical stimulation induced by ACTH gel. The percentage increase of 11-oxygenated steroids was greater than the percentage of 11-desoxy ketosteroids. Notwithstanding, the amount of 11-oxygenated steroids did not in any period exceed in absolute terms the total amount of 11-desoxysteroids in either subjects. This same pattern of response was manifest in both female subjects despite an almost 50 per cent difference in the rise in steroid excretion at the peak level.

The urinary $\beta$-ketosteroids, with dehydroisoandrosterone as the principal component, increased markedly during ACTH administration in both subjects. In fact, the increase in dehydroisoandrosterone output was proportionately the greatest of any of the compounds measured, i.e., at the peak level, about 15-fold that found during the control period of either subject. Despite the marked rise, it should be noted that the amount of this $\beta$-ketosteroid did not parallel the response to ACTH as determined by either the 11 oxygenated or 11-desoxy $\alpha$-ketosteroids. Thus, while both dehydroisoandrosterone and "dehydroisoandrosterone like substances" increase during adrenal stimulation with ACTH (12-14), it can be suggested from the disparity in the quantitative response of $\alpha$ and $\beta$ ketosteroids that different precursor-product mechanisms may be involved in the elaboration and excretion of these various compounds.

The inference that the substantial rise in 11desoxysteroids, is the reflection of a sensitive independent pathway of synthesis for an adrenal androgen, is an attractive interpretation of the results. In certain circumstances pathological overactivity of this synthetic pathway may have a clear clinical expression as in certain forms of hirsutism (2). It is interesting to note that within the confines of this increase the proportion of etiocholanolone to androsterone did not change markedly. Thus, although a C-21 precursor may have contributed to the level of the former substance during the last ACTH period, the major proportion of the 11-desoxy ketosteroids during all periods was probably derived from a C-19 precursor.

The steroid patterns during Period 6, following the termination of ACTH administration, show that both subjects manifested a selective and significant decrease in 11-desoxysteroids. This occurred despite the "masking" effect of the pooled urine collection and at a time when the 11-oxygenated steroids were at normal levels. During this "rebound," moreover, the proportion of etiocholanolone to androsterone did not undergo notable change. These findings may be interpreted as a further reflection of the existence of a selective pathway for androgen synthesis, as defined by the metabolites androsterone and etiocholanolone.

\section{SUM MARY}

The qualitative and quantitative aspects of urinary ketosteroid excretion have been studied in normal women of various ages. The data establish that the sum total of processes concerned with the biosynthesis, secretion and metabolism of the 11-oxygenated steroids examined is independent of chronological age in normal women. The secretion of 11-desoxy hormonal precursors, however, seems to diminish with increasing age. The chemical nature of the 11-desoxy steroid metabolites makes it likely that this alteration in adrenal function reflects the selective diminution in secretion of an "adrenal androgen." The response to stimulation with adrenocorticotrophic hormone has been studied in two normal women as well and was found comparable with that previously noted in normal males. The individual urinary ketosteroids were essentially at a constant level during successive periods of the menstrual cycle in two normal women. 


\section{ACKNOWLEDGMENT}

The authors express their gratitude to their colleagues Dr. Emerson Day and Dr. Louis Venet for their cooperation in the studies with patients.

The authors also wish to express their appreciation to the large group of devoted Research Assistants and Technicians who made much of the work possible. The routine chemical and chromatographic separations were carried out by a group under the supervision of Madeleine Stokem and Ruth Jandorek. The colorimetric analyses were under the supervision of Denise O'Hara. The infrared spectrometry was under the supervision of Friederike Herling. The paper chromatography separation was done by Mildred Smulowitz.

\section{REFERENCES}

1. Dobriner, K., Studies in steroid metabolism. XIX. The $\alpha$-ketosteroid excretion pattern in normal males. J. Clin. Invest., 1953, 32, 940.

2. Kappas, A., Pearson, O. H., West, C. D., and Gallagher, T. F., Steroid isolation studies in female hirsutism: evidence for adrenocortical dysfunction. J. Clin. Endocrinol. \& Metab., 1954, 14, 777.

3. Dobriner, K., Lieberman, S., and Rhoads, C. P., Studies in steroid metabolism. I. Methods for the isolation and quantitative estimation of neutral steroids present in human urine. J. Biol. Chem., 1948, 172, 241.

4. Katzenellenbogen, E. R., Dobriner, K., and Kritchevsky, T. H., Separation of steroid hormones and their metabolites by partition type chromatography. J. Biol. Chem., 1954, 207, 315.

5. Burton, R. B., Zaffaroni, A., and Keutmann, E. H., Paper chromatography of steroids. II. Corticosteroids and related compounds. J. Biol. Chem., 1951, $188,763$.

6. Savard, K., Some theoretical and some practical aspects of partition chromatography of ketosteroids.
Recent Progress in Hormone Research, 1954, IX, 185.

7. Callow, N. H., Callow, R. K., and Emmens, C. W., Colorimetric determination of substances containing the grouping $-\mathrm{CH}_{2} \mathrm{CO}-$ in urine extracts as an indication of androgen content. Biochem. J., 1938, 32, 1312.

8. Callow, N. H., Callow, R. K., Emmens, C. W., and Stroud, S. W., Methods of extracting compounds related to the steroid hormones from human urine. J. Endocrinol., 1939, 1, 76.

9. Talbot, N. B., Butler, A. M., MacLachlan, E. A., and Jones, R. N., Definition and elimination of certain errors in the hydrolysis, extraction and spectrochemical assay of $\alpha$ and $\beta$-neutral urinary 17ketosteroids. J. Biol. Chem., 1940, 136, 365.

10. Wilson, $H$., Chromogenic values of various ketosteroids in a micro modification of the Zimmermann reaction: comparison with the macro procedure. Arch. Biochem. \& Biophys., 1954, 52, 217.

11. Dobriner, K., Adrenal function and steroid excretion in disease in White, A., ed., Symposium on Steroids in Experimental and Clinical Practice. Philadelphia, The Blakiston Co., 1951, p. 130.

12. Fukushima, D. K., Leeds, N. S., Bradlow, H. L., Kritchevsky, T. H., Stokem, M. B., and Gallagher, T. F., The characterization of four new metabolites of adrenocortical hormones. J. Biol. Chem., 1955, 212, 449.

13. Ronzoni, E., The excretion of dehydroisoandrosterone during adrenal stimulation with adrenocorticotrophic hormone. J. Clin. Endocrinol. \& Metab., 1952, $12,527$.

14. Landau, R. L., Knowlton, K., Lugibihl, K., and Kenyon, A. T., The effect of adrenal stimulation with adrenocorticotrophic hormone on the excretion of dehydroisoandrosterone in man. Endocrinology, 1951, 48, 489. 